\title{
Gene mutations in cardiac arrhythmias: a review of recent evidence in ion channelopathies
}

This article was published in the following Dove Press journal:

The Application of Clinical Genetics

17 January 2013

Number of times this article has been viewed

\author{
Pi-Yin Hsiao' \\ Hui-Chun Tien² \\ Chu-Pin Lo ${ }^{2}$ \\ Jyh-Ming Jimmy Juang ${ }^{3}$ \\ Yi-Hsin Wang ${ }^{2}$ \\ Ruey J Sung ${ }^{4}$ \\ 'Institute of Life Sciences, National \\ Central University, Taoyuan, \\ Taiwan; ${ }^{2}$ Department of Financial \\ and Computational Mathematics, \\ Providence University, Taichung, \\ Taiwan; ${ }^{3}$ Cardiovascular Center \\ and Department of Cardiology, \\ National Taiwan University, Taipei, \\ Taiwan; ${ }^{4}$ Division of Cardiovascular \\ Medicine, Stanford University School \\ of Medicine, Stanford, CA, USA
}

Correspondence: Ruey Jen Sung I00 Rowan Tree Lane, Hillsborough, CA 94305, USA

Tel + I 6506851865

Fax + I 650685 I865

Email rsung@cvmed.stanford.edu

\begin{abstract}
Over the past 15 years, molecular genetic studies have linked gene mutations to many inherited arrhythmogenic disorders, in particular, "ion channelopathies", in which mutations in genes encode functional units of ion channels and/or their transporter-associated proteins in patients without primary cardiac structural abnormalities. These disorders are exemplified by congenital long QT syndrome (LQTS), short QT syndrome, Brugada syndrome (BrS) and catecholaminergic polymorphic ventricular tachycardia (CPVT). Functional and pathophysiological studies have led to better understanding of the clinical spectrum, ion channel structures and cellular electrophysiology involving dynamics of intracellular calcium cycling in many subtypes of these disorders and more importantly, development of potentially more effective pharmacological agents and even curative gene therapy. In this review, we have summarized (1) the significance of unveiling mutations in genes encoding transporter-associated proteins as the cause of congenital LQTS, (2) the technique of catheter ablation applied at the right ventricular outflow tract may be curative for severely symptomatic BrS, (3) mutations with channel function modulated by protein Kinase A-dependent phosphorylation can be the culprit of CPVT mimicry in Andersen-Tawil syndrome (LQT7), (4) ablation of the ion channel anchoring protein may prevent arrhythmogenesis in Timothy syndrome (LQT8), (5) altered intracellular $\mathrm{Ca} 2+$ cycling can be the basis of effective targeted pharmacotherapy in CPVT, and (6) the technology of induced pluripotent stem cells is a promising diagnostic and research tool as it has become a new paradigm for pathophysiological study of patient- and disease-specific cells aimed at screening new drugs and eventual clinical application of gene therapy. Lastly, we have discussed (7) genotype-phenotype correlation in relation to risk stratification of patients with congenital LQTS in clinical practice.
\end{abstract}

Keywords: Brugada syndrome, catecholaminergic polymorphic ventricular tachycardia, induced pluripotent stem cells, long QT syndrome, short QT syndrome.

\section{Introduction}

Applying the technology of DNA sequencing, ${ }^{1}$ Curran et $\mathrm{al}^{2}$ and Wang et $\mathrm{al}^{3,4}$ noted that mutations in the KCNQ1, KCNH2, and SCN5A genes, encoding the $\alpha$-subunit of ion channels that conduct potassium delayed-rectifier currents $\left(I_{\mathrm{Ks}}\right.$ and $\left.I_{\mathrm{Kr}}\right)$ and the sodium current $\left(I_{\mathrm{Na}}\right)$, respectively, could be responsible for three subtypes (LQT13 ) of congenital long-QT syndrome (LQTS). These seminal works have inspired many investigators and prompted extensive basic research, leading to subsequent identification of various gene mutations causing cardiac arrhythmias referred to as "inherited arrhythmogenic disorders" (Table 1). These arrhythmogenic disorders with mutations in genes encoding developmental components of cardiac structures produce diseases associated with a structurally abnormal heart, exemplified by hypertrophic 
Table I Inherited arrhythmogenic disorders

Mutations in genes encoding developmental components of the heart

Hypertrophic cardiomyopathy (HCM)

Arrhythmogenic right ventricular dysplasia/cardiomyopathy (ARVD/C)

Dilated cardiomyopathy (DC)

Mutations in genes encoding functional units of ion channels and/or transporter-associated proteins ("ion channelopathies")

Congenital long-QT syndrome (LQTS)

Brugada syndrome (BrS)

Catecholaminergic polymorphic ventricular tachycardia (CPVT)

Short-QT syndrome (SQTS)

cardiomyopathy, arrhythmogenic right ventricular dysplasia (cardiomyopathy), and dilated cardiomyopathy, whereas those with mutations in genes encoding functional units of ion channels and/or their transporter-associated proteins produce diseases associated with a structurally normal heart, such as congenital LQTS, short-QT syndrome, Brugada syndrome $(\mathrm{BrS})$, and catecholaminergic polymorphic ventricular tachycardia (CPVT), known as "ion channelopathies" (Tables 2-5). All these arrhythmogenic disorders are usually genetically heterogeneous, and their clinical courses are underscored by variable clinical expressivity ranging from being asymptomatic to episodic syncope, abortive cardiac arrest, and sudden cardiac death (SCD).

To confirm that a specific gene mutation is linked to cardiac arrhythmias, functional studies to illustrate consequences of the mutation are required. These functional studies usually use heterologous expression systems, primarily Xenopus oocytes, human embryonic kidney (HEK) cells, and Chinese hamster ovary cells. ${ }^{5}$ Electrophysiological effects of the mutant ion channel are then compared to those of the wild-type counterpart. However, in order to include important constituents of the macromolecular complex of an ion channel in the complex living environment so as to reproduce the exact molecular and electrophysiological phenotype, it is often necessary to generate a transgenic mouse model carrying the specific gene mutation. ${ }^{6}$

Through collaborative endeavors between clinical and basic science researchers over the past 15 years, we now have better understanding of the clinical spectrum, molecular genetics, ion-channel structures, and cellular electrophysiology relating to these inherited arrhythmogenic disorders. Taking ion channelopathies as an example, the discovery of genetic defects involving the L-type $\mathrm{Ca}^{2+}$ channel ( $\left.\mathrm{Ca}_{\mathrm{v}} 1.2\right)$, ryanodine receptor (RyR2), and calsequestrin has provided incontrovertible evidence linking cardiac arrhythmias to abnormal intracellular $\mathrm{Ca}^{2+}$ cycling. As such, research and development of targeted pharmacotherapy and/or gene therapy can be contemplated. In this review, we focus on unique findings that have been recently described; in particular those pertaining to the underlying pathophysiology for better diagnosis and development of new targeted treatment modalities in certain ion channelopathies.

\section{Mutations in genes encoding transporter-associated proteins as the cause of congenital LQTS}

Congenital LQTS is an inherited disorder of delayed cardiac repolarization, electrocardiographically reflected as QT-interval prolongation, with a propensity to lethal ventricular tachyarrhythmias causing recurrent syncope, seizures, and SCD. ${ }^{7}$ Molecular genetic studies have demonstrated that three subtypes of congenital LQTS-LQT1,

Table 2 Congenital long-QT syndrome (LQTS)

\begin{tabular}{|c|c|c|c|c|c|}
\hline Name & Current & $\begin{array}{l}\text { Gain/loss of } \\
\text { function }\end{array}$ & Protein & Gene & Reference \\
\hline LQTI & $I_{\mathrm{Ks}}$ & Loss & $\mathrm{K}_{\mathrm{v}} \mathrm{LQTI}$ & $K C N Q I$ & Wang et $\mathrm{a}^{3}$ \\
\hline LQT2 & $I_{\mathrm{Kr}}$ & Loss & $\mathrm{K}_{\mathrm{v}} \mathrm{II} . \mathrm{I}$ & $\mathrm{KCNH} 2$ & Curran et $\mathrm{al}^{2}$ \\
\hline LQT3 & $I_{\mathrm{Na}}$ & Gain & $\mathrm{Na}_{v} 1.5$ & SCN5A & Wang et $\mathrm{al}^{4}$ \\
\hline LQT4 & $I_{\mathrm{NCX}}, I_{\mathrm{NaK}}, \operatorname{Ins} \mathrm{P}_{3} \mathrm{R}$ & Loss & Ankyrin-B & $A N K B$ & Mohler et $\mathrm{al}^{9}$ \\
\hline LQT5 & $I_{\mathrm{Ks}}$ & Loss & MinK & KCNEI & Splawski et al ${ }^{93}$ \\
\hline LQT6 & $I_{\mathrm{Kr}}$ & Loss & MiRPI & KCNE2 & Abbott et $\mathrm{al}^{94}$ \\
\hline LQT7 & $I_{\mathrm{K} I}$ & Loss & Kir2.I & KCN/2 & Plaster et $a l,{ }^{16} \mathrm{Ai}$ et $\mathrm{al}{ }^{95}$ \\
\hline LQT8 & $\hat{I}_{C a, L}$ & Gain & $\mathrm{Ca}_{v} \mid .2 \alpha \mathrm{I}$ & CACNAIC & Splawski et al ${ }^{25}$ \\
\hline LQT9 & $I_{\mathrm{Na}}$ & Gain & Caveolin-3 & CAV3 & Vatta et $a l,{ }^{10} \mathrm{Ye}$ et $\left.\mathrm{a}\right|^{96}$ \\
\hline LQTIO & $I_{\mathrm{Na}}$ & Gain & $\mathrm{Na}_{\mathrm{v}} \beta 4$ & SCN4B & Domingo et al, ${ }^{97}$ Medeiros-Domingo et $\mathrm{a}^{98}$ \\
\hline LQTII & $I_{\mathrm{Ks}}$ & Loss & Yotiao & AKAPQ & Chen et $\mathrm{al}^{13}$ \\
\hline LQTI2 & $I_{\mathrm{Na}}^{\mathrm{Ks}}$ & Gain & $\alpha$-I Syntrophin & SNTAI & Ueda et al, ${ }^{99} \mathrm{Wu}$ et al ${ }^{100}$ \\
\hline LQTI3 & $I_{\text {K-Ach }}$ & Loss & Kir3.4 & KCNJ5 & Yang et al ${ }^{101}$ \\
\hline
\end{tabular}

Abbreviations: $I_{\mathrm{Kr}}$ and $I_{\mathrm{Ks}}$, rapid and slow delayed-rectifier potassium currents respectively; $I_{\mathrm{Na}}$, sodium current; $I_{\mathrm{NCX}}, \mathrm{Na}^{+} / \mathrm{Ca}^{2+}$ exchanger current; $I_{\mathrm{Nak}}, \mathrm{Na}^{+} / \mathrm{K}^{+} \mathrm{ATPase}$ (pump) current; InsP $\mathrm{R}_{3}$, inositol I,4,5-trisphosphate (IP3) receptors; $I_{\mathrm{Kl}}$, inward-rectifier potassium current; $I_{\text {Ca, }}$, L-type calcium current; $I_{\mathrm{K} \text {-Ach' }}$, acetylcholine-regulated potassium current. 
Table 3 Brugada syndrome $(\mathrm{BrS})$

\begin{tabular}{|c|c|c|c|c|c|}
\hline Name & Current & Gain/loss of function & Protein & Gene & Reference \\
\hline \multirow[t]{2}{*}{$\mathrm{BrSI}$} & $I_{\mathrm{Na}}$ & Loss & $\mathrm{Na}_{\mathrm{v}} \mathrm{I} .5$ & SCN5A & Chen et al, ${ }^{54}$ Kapplinger et al, ${ }^{102}$ \\
\hline & & & & & Schulze-Bahr et al ${ }^{103}$ \\
\hline $\mathrm{BrS2}$ & $I_{\mathrm{Na}}$ & Loss & & GPDI-L & London et $\mathrm{al}^{56}$ \\
\hline $\mathrm{BrS3}$ & $I_{\mathrm{Ca}, \mathrm{L}}$ & Loss & $\mathrm{Ca}_{\mathrm{v}} \mid .2 \alpha \mathrm{I}$ & CACNAIC & Antzelevitch et $\mathrm{al}^{58}$ \\
\hline $\mathrm{BrS} 4$ & $I_{\mathrm{Ca}, \mathrm{L}}$ & Loss & $\mathrm{Ca}_{v} \beta_{2 \mathrm{~b}}$ & $C A C N B 2 b$ & Antzelevitch et $\mathrm{al}^{58}$ \\
\hline $\mathrm{BrS5}$ & $I_{\mathrm{Na},}$ & Loss & $\mathrm{Na}_{v} \beta \mathrm{I}$ & $S C N I B$ & Watanabe et $\mathrm{al}^{5}$ \\
\hline $\mathrm{BrS6}$ & $I_{\text {to }}$ & Gain & MiRP2 & KCNE3 & Delpón et $a^{60}$ \\
\hline $\mathrm{BrS7}$ & $I_{\mathrm{Na}}$ & Loss & $\mathrm{Na}_{v} \beta 3$ & $S C N 3 B$ & Hu et $\mathrm{al}^{55}$ \\
\hline $\mathrm{BrS8}$ & $I_{\text {K-ATP }}$ & Gain & Kir6.I & KCNJ8 & Medeiros-Domingo et al ${ }^{104}$ \\
\hline $\mathrm{BrS9}$ & $I_{\mathrm{C}, \mathrm{L}}$ & Loss & $\mathrm{Ca}_{v} \alpha 2 \mathrm{~d}$ & CACNA2DI & Burashnikov et $\mathrm{al}^{59}$ \\
\hline $\mathrm{BrSIO}$ & $l_{\text {to }}$ & Gain & $\mathrm{K}_{\mathrm{v}} 4.3$ & KCND3 & Giudicessi et al ${ }^{105}$ \\
\hline $\mathrm{BrSII}$ & $I_{\mathrm{Na}}$ & Loss & & MOGI & Kattygnarath et $\mathrm{al}^{57}$ \\
\hline $\mathrm{BrSI} 2$ & $I_{\text {K-ATP }}$ & Gain & SUR2A & $A B C C 9$ & Barajas-Martínez et al ${ }^{61}$ \\
\hline
\end{tabular}

Abbreviations: $I_{\mathrm{Na}}$, sodium current; $I_{\mathrm{Ca}, \mathrm{L}}$, L-type calcium current; $I_{\text {to }}$, transient outward current; $I_{\mathrm{K}-\mathrm{ATP}}$, ATP-dependent potassium current.

LQT2, and LQT3 - constitute 65\%-75\%, while each in the remaining susceptibility genes accounts for $<1 \%$, leaving approximately $20 \%-25 \%$ of patients with a yet-to-bedetermined genotype. ${ }^{8}$

While congenital LQTS is predominantly caused by mutations in genes that encode ion channels, the discovery that transporter-associated proteins could also be the culprit is of diagnostic and therapeutic importance. ${ }^{8}$ Following identification of mutations in ankyrin-B (ankyrin 2) as the cause for LQT4, ${ }^{9}$ those in caveolin-3 (CAV3), yotiao (AKAP9), and $\alpha$-1-syntrophin have been found to be responsible for LQT9, LQT11, and LQT12, respectively. ${ }^{8}$

\section{LQT4}

Ankyrin-B, a membrane adapter, binds to multiple proteins that can directly or indirectly contribute to cardiac electrical activity. ${ }^{9}$ These multiple proteins include $\mathrm{Na}^{+}$channels $\left(\mathrm{Na}_{\mathrm{v}} 1.5\right), \mathrm{Cl}^{-} / \mathrm{HCO}_{3}^{-}$exchanger, $\mathrm{Na}^{+} / \mathrm{K}^{+}$ adenosine triphosphatase (ATPase), Kir6.2, and $\mathrm{Ca}^{2+}$ release channels such as those mediated by RyR2 or inositol 1,4,5-trisphosphate (IP3) receptors. LQT4 is caused by mutations of ankyrin-B that result in loss of function. ${ }^{9}$ As has been shown in a heterozygous mouse model of null ankyrin-B, loss of ankyrin-B function disrupts the cellular organization of these ankyrin-B-binding proteins, leading to intracellular $\mathrm{Ca}^{2+}$ overload and store-overload-induced $\mathrm{Ca}^{2+}$ release (SOICR) from the sarcoplasmic reticulum (SR), triggering afterdepolarizations in response to catecholaminergic stimulation. ${ }^{9}$ Clinically, LQT4 patients manifest mild QT prolongation, catecholamine-sensitive polymorphic ventricular tachycardia (VT), and SCD, and may also present with sinus bradycardia, atrial fibrillation and atrioventricular conduction defects. ${ }^{8}$

\section{LQT9}

Caveolae are flask-shaped invaginations of the plasma membrane involved in vesicular trafficking and signaltransduction pathways, in which caveolins are the principal proteins. Cardiac ion channels that are specifically localized to caveolae include $\mathrm{Na}_{\mathrm{v}} 1.5$, the voltage-dependent $\mathrm{K}^{+}$channel $\left(\mathrm{K}_{\mathrm{v}} 1.5\right), \mathrm{Na}^{+} / \mathrm{Ca}^{2+}$ exchanger, and $\mathrm{Ca}_{\mathrm{v}} 1.2$; in addition, a variety of other signaling molecules, including $\beta_{2}$-adrenergic receptors and associated proteins of the G-protein/adenylyl cyclase/protein kinase A (PKA) pathway, have been found in caveolae. LQT9 is caused by mutations of $C A V 3$, with resultant interference of signaling between caveolae-enriched ion channels and a network of integrated signaling molecules. ${ }^{8,10}$ Of interest, in $C A V 3$ knockout mice, progressive cardiac hypertrophy/ cardiomyopathy is observed, ${ }^{11}$ and in HEK293 cell lines mutant $C A V 3$ exhibits a two- to threefold increase in late $\mathrm{Na}^{+}$current

Table 4 Catecholaminergic polymorphic ventricular tachycardia (CPVT)

\begin{tabular}{|c|c|c|c|c|c|}
\hline Name & Current & Gain/loss of function & Protein & Gene & Reference \\
\hline CPVTI & $I_{\text {rel }}$ & Leak & RyR2 & $R y R 2$ & Laitinen et al, ${ }^{106}$ Priori et al ${ }^{107}$ \\
\hline CPVT2 & $I_{\text {rel }}$ & Leak & Calsequestrin & CASQ2 & Lahat et al, ${ }^{108}$ Postma et al ${ }^{109}$ \\
\hline CPVT3 & $I_{\mathrm{KI}}$ & Loss & Kir2.I & KCNJ2 & Tester et al, ${ }^{22}$ Postma et al ${ }^{110}$ \\
\hline CPVT4 & $I_{\mathrm{NCX}}, I_{\mathrm{NaK}}, \operatorname{InsP}_{3} \mathrm{R}$ & Loss & Ankyrin-B & ANKB & Mohler et al'II \\
\hline
\end{tabular}

Abbreviations: RyR2, ryanodine receptor; $I_{\text {rel }}, \mathrm{RyR} 2 \mathrm{Ca}^{2+}$ release current; $I_{\mathrm{Kl}}$, inward-rectifier potassium current; $I_{\mathrm{NCx}}, \mathrm{Na}^{+} / \mathrm{Ca}^{2+}$ exchanger current, $I_{\mathrm{NaK}}, \mathrm{Na}^{+} / \mathrm{K}^{+}$ATPase (pump) current; $\operatorname{InsP}_{3} \mathrm{R}$, inositol I,4,5-trisphosphate (IP3) receptors. 
Table 5 Short-QT syndrome (SQTS)

\begin{tabular}{|c|c|c|c|c|c|}
\hline Name & Current & $\begin{array}{l}\text { Gain/loss of } \\
\text { function }\end{array}$ & Protein & Gene & Reference \\
\hline SQTI & $I_{\mathrm{Kr}}$ & Gain & $K_{v} I I . I$ & $\mathrm{KCNH} 2$ & Brugada et al ${ }^{1 / 2}$ \\
\hline SQT2 & $I_{\mathrm{Ks}}$ & Gain & K LQTI & KCNQI & Bellocq et $\mathrm{al}^{1 / 3}$ \\
\hline SQT3 & $I_{\mathrm{K} I}^{\mathrm{Ks}}$ & Gain & Kir2.I & KCNJ2 & Priori et al ${ }^{1 / 4}$ \\
\hline SQT4 & $I_{\mathrm{Ca}, \mathrm{L}}^{\mathrm{KI}}$ & Loss & $\mathrm{Ca}_{\mathrm{v}} \mid .2 \alpha \mathrm{I}$ & CACNAIC & Antzelevitch et $\mathrm{al}^{58}$ \\
\hline SQT5 & $I_{\mathrm{Ca}_{\mathrm{a}, \mathrm{L}}}$ & Loss & $\mathrm{Ca}_{\mathrm{v}} \beta_{2 \mathrm{~b}}$ & $C A C N B 2 b$ & Antzelevitch et $\mathrm{al}^{58}$ \\
\hline SQT6 & $I_{\mathrm{Ca}_{\mathrm{L}} \mathrm{L}}$ & Loss & $\mathrm{Ca}_{\mathrm{v}} \alpha_{2} \delta-\mathrm{I}$ & CACNA2DI & Templin et al ${ }^{115}$ \\
\hline
\end{tabular}

Abbreviations: $I_{\mathrm{Kr}}$ and $I_{\mathrm{Ks}}$, rapid and slow delayed-rectifier potassium currents, respectively; $I_{\mathrm{KI}}$, inward-rectifier potassium current; $I_{\mathrm{Ca}}, \mathrm{L}^{\prime}$ L-type calcium current.

similar to that seen in LQT3-associated SCN5A mutations. ${ }^{10}$ Moreover, $C A V 3$ mutations are also linked to sudden infant death syndrome. ${ }^{12}$ However, because of multiple ion-channel involvement, the exact mechanisms by which $C A V 3$ mutations exert arrhythmogenesis remain to be determined. ${ }^{8}$

\section{LQTII}

Yotiao (AKAP9) is a member of a family of PKA-anchoring proteins. LQT11 is due to mutations of $A K A P 9$ that is required to be assembled with the $\alpha$-subunit of the $I_{\mathrm{Ks}}$ channel (K LQT1) during $\beta_{2}$-adrenergic activation (BAS); AKAP9-associated PKA activity is also connected with activities of RyR2 and $\mathrm{Ca}_{\mathrm{v}} 1.2$. Hence, mutations of this PKA-anchoring protein interfere with PKA-dependent phosphorylation, thereby markedly inhibiting responses of at least three ion channels, ie, $\mathrm{K}_{\mathrm{v}} \mathrm{LQT1}$ 1, RyR2, and $\mathrm{Ca}_{\mathrm{v}} 1.2$, to cyclic adenosine monophosphate (cAMP). ${ }^{13}$ Clinically, LQT11 is likened to LQT1 and LQT5. ${ }^{8}$

\section{LQTI2}

$\alpha$-1-Syntrophin belongs to a family of cytoplasmic adapter proteins, linking many membrane proteins and signaling molecules, including plasma membrane calcium ATPase and neuronal nitric oxide synthase (nNOS); nNOS can directly affect persistent (or late) $I_{\mathrm{Na}}$, and variants in the nNOS regulatory protein NOS1AP (CAPON) can regulate and moderate the QT interval. ${ }^{14,15}$ LQT12 is related to mutations of $\alpha-1$-syntrophin, which cause a decrease in its binding activity for plasma membrane calcium ATPase and nNOS along with an increase in $\mathrm{Na}_{\mathrm{v}} 1.5$ nitrosylation; the resultant persistent $I_{\mathrm{Na}}$ creates a clinical phenotype akin to LQT3. ${ }^{8}$

\section{Mutations with channel function modulated by PKA-dependent phosphorylation as the cause of CPVT mimicry in LQT7 (Andersen-Tawil syndrome)}

Andersen-Tawil syndrome (ATS) (LQT7) is an autosomal dominant disorder clinically characterized by ventricular arrhythmias associated with long QT interval, periodic paralysis, and multiple skeletal dysmorphic features. ${ }^{16-18}$ More than 20 mutations have been identified in the KCNJ2 gene, which encodes the $\alpha$-subunit of the inward-rectifier potassium channel (Kir2.1). ${ }^{16-18}$

Electrophysiologically, the corresponding Kir2.1 current $\left(I_{\mathrm{K} 1}\right)$ participates in the terminal phase of action potential (AP) repolarization responsible for setting the resting membrane potential in mammalian heart cells. ${ }^{19}$ Of the mutations identified in distinct regions of KCNJ2 in ATS patients, a dominant negative effect of the mutant allele can be found in both trafficking and non-trafficking defective channels, contributing to loss of Kir2.1 function. ${ }^{20}$

Although patients with ATS have a high prevalence (approximately 64\%) of ventricular arrhythmias, ${ }^{16,17}$ these arrhythmias are usually not related to exercise and/or emotional distress. The relatively benign clinical course is attributed to lack of significant enhancement of transmural dispersion of repolarization produced by $I_{\mathrm{K} 1}$ down-regulation. ${ }^{21}$ However, a subset of ATS patients, especially females, are prone to exercise- and/or stress-induced bidirectional VT and/or polymorphic VT, mimicking CPVT, ${ }^{17,20,22,23}$ which is a malignant form of inherited arrhythmogenic disorder, affecting the young with otherwise a structurally normal heart and QT interval. ${ }^{24}$ However, mutations of CPVT are primarily (approximately $60 \%$ of patients) located in the gene encoding RyR2 (CPVT1, autosomal dominant) or calsequestrin (CPVT2, autosomal recessive) in SR.

Molecular genetic studies have identified several mutations in the KCJN2 gene, such as G144D, R67W, R82W, R260P, $\mathrm{T} 305 \mathrm{~S}$, and $\mathrm{V} 227 \mathrm{~F},{ }^{20,22,23}$ that may predispose ATS patients to catecholamine-sensitive ventricular tachyarrhythmias, regarded as CPVT mimicry or CPVT3. ${ }^{17,20,22,23}$ Of interest, among these mutations, heterozygous Kir2.1-V227F can function normally like wild-type channels. ${ }^{23}$ However, when stimulated by cAMP-dependent PKA, the Kir2.1-V227F mutant can significantly downregulate $I_{\mathrm{K} 1}$. This unique biophysical property of latent loss of function modulated 
by PKA-dependent phosphorylation of the $I_{\mathrm{K} 1}$ channel provides a rather specific mechanism by which a subset of ATS patients may manifest ventricular arrhythmias under high adrenergic tone, simulating the phenotype of CPVT.

\section{Ablation of the ion channel-anchoring protein may prevent arrhythmogenesis in LQT8 (Timothy syndrome)}

Timothy syndrome (TS), a subtype (LQT8) of congenital LQTS, clinically manifests multisystem involvement (eg, syndactyly, dysmorphic facial features, autism, etc). ${ }^{25}$ In association with marked QT-interval prolongation, cardiac arrhythmias are the most serious aspect of its clinical features. These include bradycardia, atrioventricular block, polymorphic VT, and ventricular fibrillation (VF). Because of high prevalence $(71 \%)$ and severity of VT/VF, the majority of TS patients seldom survive beyond 3 years of age. ${ }^{25,26}$ Notably, the mode of induction of cardiac events (eg, syncope, cyanotic spell, and SCD) is usually triggered by an increase in sympathetic tone.

Molecular genetic studies have revealed that TS patients have mutations with a Gly to Arg substitution at position 406 (G406R) of $\mathrm{Ca}_{\mathrm{v}} 1.2$ in the CACNA1C gene, which results in "near-complete" elimination of voltage-dependent inactivation (VDI) of $\mathrm{Ca}_{\mathrm{v}} 1.2$ (gain of function). ${ }^{25,26}$ Electrophysiological studies have illustrated that G406R-mutated $\mathrm{Ca}_{\mathrm{v}} 1.2$ is inactivated at a slow rate ${ }^{25}$ alongside a high probability of undergoing coordinated openings and closings (coupled gating). ${ }^{27}$

It is suggested that G436R-mutated $\mathrm{Ca}_{\mathrm{v}} 1.2$ (corresponding to G406R in humans) in rabbit ventricular myocytes creates a new phosphorylation site (Ser-439) for $\mathrm{Ca}^{2+} /$ calmodulindependent protein kinase II (CaMKII), and phosphorylation of this site is correlated with an increased open probability of gating of the mutant cardiac $\mathrm{Ca}_{\mathrm{v}} 1.2 .^{28}$ Unfortunately, others have demonstrated that phosphorylation by CaMKII is not necessary for the slower rate of $\mathrm{Ca}_{\mathrm{v}} 1.2$ inactivation. ${ }^{27,29}$ Moreover, in exogenously expressed (HEK293 cells) rabbit cardiac $\mathrm{Ca}_{\mathrm{v}} 1.2$, it is shown that the G436R mutation displays multiple altered gating mechanisms of $\mathrm{Ca}_{\mathrm{v}} 1.2 .{ }^{29}$ Besides affecting the open-state VDI, it significantly slows the channel activation at voltages less than $10 \mathrm{mV}$ and disturbs its deactivation across, the latter of which also favors a high open-probability state of $\mathrm{Ca}_{\mathrm{v}} 1.2$ (also arrhythmogenic). ${ }^{30}$ Surprisingly, the closed state of VDI remains intact, suggesting that two different gating mechanisms are involved in the open and closed states of VDI. Collectively, these findings imply that impaired open state of VDI and slowed deactivation of $\mathrm{Ca}_{\mathrm{v}} 1.2$ can synergistically increase $\mathrm{AP}$ duration and cause early and delayed afterdepolarizations (EADs and DADs) and triggered activity (TA) due to $\mathrm{Ca}^{2+}$ overload. ${ }^{25,31}$ Experimentally, roscovitine, an open-state VDI enhancer, can revert functional defects of the mutated $\mathrm{Ca}_{\mathrm{v}} 1.2 .^{29}$

Recently, in ventricular myocytes obtained from a transgenic mouse model that expresses $\mathrm{Ca}_{\mathrm{v}} 1.2-\mathrm{LQT} 8$, the mutated $\mathrm{Ca}_{\mathrm{v}} 1.2$ is shown to be abnormally coupled to AKAP150, a specific protein kinase that phosphatases to regions near $\mathrm{Ca}_{\mathrm{v}} 1.2 .{ }^{32} \mathrm{With}$ the formation of this aberrant ion channel-anchoring protein complex, AKAP150 functionally serves like a channel subunit that stabilizes the open conformation and augments the probability of coordinated openings, enhancing $\mathrm{Ca}_{\mathrm{v}} 1.2-\mathrm{LQT} 8$ currents. Of note, ablation of AKAP150 restores normal gating (inactivation) of $\mathrm{Ca}_{\mathrm{v}} 1.2-\mathrm{LQT} 8$, thereby preventing EADs, DADs, and torsade des pointes. Hence, it appears that AKAP150 is required for increased $\mathrm{Ca}_{\mathrm{v}} 1.2$ activity and coupled gating seen in LQT8 ventricular myocytes. Since AKAP150 also binds to the carboxyl tail of $\mathrm{Ca}_{\mathrm{v}} 1.2$ via leucine-zipper motifs, it is postulated that AKAP150 binds to the C-terminal tail of $\mathrm{Ca}_{\mathrm{v}} 1.2-\mathrm{LQT} 8$, thereby facilitating longer channel openings and interaction between multiple $\mathrm{Ca}_{\mathrm{v}}$ 1.2-LQT8 channels to increase the frequency of "coupled gating"; consequently, greater $\mathrm{Ca}^{2+}$ influx leads to intracellular $\mathrm{Ca}^{2+}$ overload. This unique AKAP150-dependent change in $\mathrm{Ca}_{\mathrm{v}} 1.2$ LQT8 gating may represent an important mechanism of arrhythmogenesis in LQT8.

\section{Altered intracellular $\mathrm{Ca}^{2+}$ cycling and targeted pharmacotherapy for CPVT}

CPVT is an inherited arrhythmogenic disorder characterized by episodic syncope occurring during physical activity or acute emotional distress in individuals with otherwise normal hearts and electrocardiograms (ECGs). Notably, episodes of syncope usually coincide with documented bidirectional or polymorphic VT that may degenerate into VF. By the age of 40 years, cardiac events occur in $80 \%$ of patients, and the mortality rate can be as high as $30 \%-50 \% .{ }^{24}$ In $60 \%$ of CPVT patients, molecular genetic studies have revealed that mutations are mostly located in the gene encoding RyR2 (autosomal dominant) and rarely in the calsequestrin gene (CASQ2, autosomal recessive).

Although more than 70 RyR2 mutations have been identified in CPVT, mechanisms by which RyR2 mutations 
alter the properties of RyR2 receptors, thereby generating ventricular tachyarrhythmias, remain highly debatable. The general consensus is that RyR2 mutations lead to abnormally augmented $\mathrm{Ca}^{2+}$ release, resulting in DADs and DAD-mediated TA. ${ }^{24}$ In an RyR ${ }^{\mathrm{R} 4496 \mathrm{C}}$ knock-in mouse model (equivalent to human R4497C mutation), it has been demonstrated that (1) $\mathrm{RyR}^{+} / \mathrm{RyR}^{\mathrm{R} 4496 \mathrm{C}}$ mice are prone to bidirectional VT after catecholaminergic stimulation and that VT can degenerate into VF; ${ }^{33}$ (2) DADs and DAD-mediated TA induced by isoproterenol can be abolished by ryanodine but not by K201 (an agent that enhances binding of FKBP12.6 to RyR2); ${ }^{34}$ (3) there is an increase in $\mathrm{Ca}^{2+}$ sensitivity of RyR2 conjoined with a lowered SOICR threshold; $;{ }^{35}$ (4) there is elevation of SR $\mathrm{Ca}^{2+}$ load in the absence of BAS; ouabain, an $\mathrm{Na}^{+} / \mathrm{K}^{+}$-ATPase antagonist, can enhance the propensity to DADs and TA, and that JTV-519, a RyR2 stabilizer, can effectively reduce these arrhythmias; ${ }^{36}$ and (5) Purkinje cells of RyR2 ${ }^{+} / \mathrm{RyR}^{\mathrm{R} 4496 \mathrm{C}}$ mice are more vulnerable than the ventricular myocyte to altered intracellular $\mathrm{Ca}^{2+}$ cycling leading to EADs, DADs, and TA, which can be greatly exacerbated by BAS. ${ }^{37}$ Taken together, these latter findings suggest that medications like digitalis are contraindicated and that Purkinje cells are critical contributors to arrhythmogenesis in CPVT similar to many other clinical situations, eg, after myocardial infarction, in the presence of dilated cardiomyopathy or idiopathic VF, and with other inherited ion channelopathies, including $\mathrm{BrS}$ and LQTS. ${ }^{38}$

Missense mutations of CASQ2 have been shown to alter the $\mathrm{Ca}^{2+}$-binding capacity and/or the $\mathrm{Ca}^{2+}$-dependent polymerization of calsequestrin. It seems that mechanistically different defects in CASQ2 all lead to increased diastolic $\mathrm{SR} \mathrm{Ca}^{2+}$ release and manifest a similar CPVT phenotype. It is illustrated that expression of truncated $C A S Q 2^{\mathrm{DEL}}$ $(\mathrm{G} 112+15 \mathrm{X})$ and $C A S Q 2^{\mathrm{R} 33 \mathrm{Q}}$ mutations can alter myocyte $\mathrm{Ca}^{2+}$ signaling through two distinctly different mechanisms: ${ }^{39}$ $C A S Q 2^{\text {DEL }}$ mutation disrupts the polymerization of calsequestrin required for high-capacity $\mathrm{Ca}^{2+}$ binding, whereas $C A S Q 2^{\mathrm{R} 33 \mathrm{Q}}$ mutation compromises the ability of calsequestrin to control the RyR2 channel activity. Consequently, with $C A S Q 2^{\mathrm{DEL}}$ mutation, local $\mathrm{Ca}^{2+}$ release terminates at the same free luminal $\mathrm{Ca}^{2+}$ concentrations as those of the wild type. In contrast, with $C A S Q 2^{\mathrm{R} 33 \mathrm{Q}}$ mutation, compromised interactions between RyR2 and calsequestrin markedly lower the threshold of luminal $\mathrm{Ca}^{2+}$ concentrations for the termination of $\mathrm{SR} \mathrm{Ca}^{2+}$ release. These findings suggest that calsequestrin possesses dual function by providing a local source of releasable $\mathrm{Ca}^{2+}$ and by exerting effects on luminal $\mathrm{Ca}^{2+}$-dependent $\mathrm{RyR} 2$ gating (ie, via protein-protein interactions or serving as a luminal $\mathrm{Ca}^{2+}$ sensor).$^{40}$ It should be noted, however, calsequestrin-null mice are viable and display normal $\mathrm{SR} \mathrm{Ca}^{2+}$ release and contractile function under basal conditions while still maintaining functional SR $\mathrm{Ca}^{2+}$ storage. Despite lack of calsequestrin, calsequestrin-null mice exhibit an increase in diastolic SR $\mathrm{Ca}^{2+}$ leak without apparent upregulation of other $\mathrm{Ca}^{2+}$-binding proteins and are susceptible to CPVT-related ventricular arrhythmias, especially under BAS. Thus, although calsequestrin modulates $\mathrm{SR} \mathrm{Ca}^{2+}$ release, it is not essential for luminal $\mathrm{Ca}^{2+}$ regulation of RyR2, nor is it required for SOICR termination in cardiac myocytes. Currently, the consensus is that the luminal $\mathrm{Ca}^{2+}$ sensor lies within the RyR2 complex, likely to be regulated by a number of accessory proteins, such as calsequestrin, triadin, junctin, FKBP12.6, calmodulin, kinases, and others associated with the RyR2 complex. ${ }^{41}$

It has been shown that heterozygous $\mathrm{CASQ}^{\mathrm{K} 206 \mathrm{~N}}$ missense mutation can generate an additional $\mathrm{N}$-glycosylation site, which can result in the recombinant protein having a higher molecular weight with reduced $\mathrm{Ca}^{2+}$-binding capacity exhibiting an altered aggregation state; consequently, despite the interaction of CASQ ${ }^{\mathrm{K} 206 \mathrm{~N}}$ with triadin and the protein level of RyR2 remaining unchanged, the response of the CASQ ${ }^{\mathrm{K} 206 \mathrm{~N}}$ myocyte to caffeine is impaired, as there is a lower SR $\mathrm{Ca}^{2+}$ load alongside a higher opening state of RyR2. Therefore, the CASQ ${ }^{\mathrm{K} 206 \mathrm{~N}}$ myocyte displays a higher rate of spontaneous $\mathrm{SR} \mathrm{Ca}^{2+}$ release under basal conditions and under BAS compared to the wild-type counterpart. ${ }^{42}$

Clinical observations have shown that $\beta$-blockers provide only incomplete protection, and other antiarrhythmic agents, such as quinidine, verapamil, and amiodarone, are either ineffective or only partially efficacious in CPVT. ${ }^{43}$ Some patients need to resort to implantable cardioverter/ defibrillators, left cardiac sympathetic denervation, and even to cardiac transplantation. ${ }^{24}$ Based on better understanding of the pathophysiology of CVPT, targeted pharmacotherapy appears to be very promising. ${ }^{43,44}$ Recently, flecainide therapy has been advocated to be efficacious in suppressing ventricular arrhythmias in CPVT as well as certain ATS patients. ${ }^{20,45-47}$ Flecainide directly inhibits RyR 2 by perturbing RyR2-mediated premature $\mathrm{Ca}^{2+}$ release, thereby suppressing arrhythmogenic $\mathrm{Ca}^{2+}$ waves and effectively suppressing ventricular arrhythmias in CASQ2 knockout mice. ${ }^{45,47}$ However, flecainide is a potent $\mathrm{Na}^{+}$-channel inhibitor that also blocks $I_{\mathrm{Kr}}$ and $\mathrm{Ca}^{2+}$-independent transient outward $\mathrm{K}^{+}$ current. ${ }^{48}$ Being a potent $\mathrm{Na}^{+}$-channel inhibitor, it decreases the probability for DADs to reach the threshold for AP generation. ${ }^{49}$ Moreover, it selectively increases the density 
of functional Kir2.1 via reducing Kir2.1 polyamine blockade in the human ventricular myocyte. ${ }^{50}$ Although the exact mechanism whereby flecainide exerts its antiarrhythmic action is complex, the therapeutic efficacy of flecainide in CPVT patients has been clinically confirmed. ${ }^{46}$

For targeted pharmacotherapy, simulated electropharmacological testing suggests that combination therapy with a $\mathrm{Ca}^{2+}$-channel blocker and an $I_{\text {up }}$ (SR $\mathrm{Ca}^{2+}$-ATPase current) inhibitor is more efficacious than a $\mathrm{Ca}^{2+}$-channel blocker alone in suppressing CPVT-associated arrhythmias. ${ }^{31}$ Furthermore, in RyR $\mathrm{R}^{\mathrm{R} 496 \mathrm{C}+/-}$ knock-in mice, CaMKII overexpression enhances RyR2 phosphorylation and increases the propensity to TA; KN93, a CaMKII inhibitor, prevents TA via counteracting effects of BAS. ${ }^{51}$ Thus, tackling a specific site in intracellular $\mathrm{Ca}^{2+}$ cycling appears logical and promising for suppressing cardiac arrhythmias associated with CPVT.

\section{Catheter ablation of the right ventricular outflow tract may be curative for severely symptomatic BrS}

$\mathrm{BrS}$ is an inherited arrhythmogenic disorder that exhibits ECG ST-segment elevation with a negative T-wave in the right precordial leads $\left(\mathrm{V}_{1}-\mathrm{V}_{3}\right)$, predisposing to $\mathrm{VF}$ and $\mathrm{SCD}$ in otherwise healthy individuals. ${ }^{52} \mathrm{BrS}$ is recognized as an important cause of SCD in young men, especially in Southeast Asia. ${ }^{53}$ Notably, the Brugada ECG pattern is dynamic and functional; it is more pronounced at night or at rest and may be enhanced by an increase in vagal tone, such as at night or after a big meal, and may become apparent during a febrile illness. Of note, sodium-channel blockers (class 1A and 1C) and acetylcholine may enhance or provoke the Brugada ECG pattern, facilitating the diagnosis of the syndrome. ${ }^{52}$

Genetically, mutations in eleven genes have been identified in patients with BrS. Most of these mutations are located in $S C N 5 A$, encoding the $\alpha$-subunit of $\mathrm{Na}_{\mathrm{v}} 1.5,{ }^{54}$ in $S C N 1 B^{5}$ and $S C N 3 B,{ }^{55}$ encoding the $\beta$-subunits of the cardiac sodium channel, or in GPD $1 L^{56}$ and $M O G 1,{ }^{57}$ involving the trafficking of $\mathrm{Na}_{\mathrm{v}} 1.5$ to the cell membrane; all of these mutations result in loss of function of $\mathrm{Na}_{\mathrm{v}} 1.5$, thereby reducing $I_{\mathrm{Na}}$. Other mutations are located in $C A C N A 1 C, C A C N B 2 b^{58}$ and $C A C N A 2 D 1,{ }^{59}$ which encode $\alpha 1-, \beta_{2 b}{ }^{-}$, and $\alpha 2 \delta 1$-subunits of $\mathrm{Ca}_{\mathrm{v}} 1.2$, respectively, with resultant reduction of the L-type calcium current $\left(I_{\mathrm{Ca}, \mathrm{L}}\right)$ and in $K C N E 3$, encoding MiRP2, $\alpha$-, and $\beta$-subunits of several potassium channels, ${ }^{60}$ and in $K C N J 8$, encoding the
ATP-sensitive potassium channel. ${ }^{61}$ Overall, mutations in SCN5A account for approximately $20 \%$ and those in other genes $10 \%$, leaving no definitive genetic defects in $70 \%$ of BrS patients. ${ }^{52}$ Although the heart appears grossly normal, right ventricular structural abnormalities, such as fibrofatty degenerative changes, lymphocytic myocarditis, and atypical cardiomyopathic alterations in the ventricular outflow tract (RVOT) are not infrequently observed. Clinical features overlapping with the right ventricular dysplasia/ cardiomyopathy, another form of inherited arrhythmogenic disorder with distinctly abnormal right ventricle (Table 1), have been reported. Differential diagnosis between the two may at times present as a clinical dilemma. ${ }^{52}$

Despite the discovery of various genetic mutations, the pathophysiology underpinning $\mathrm{BrS}$ remains elusive. There has been much debate about whether it is a depolarization disorder (ie, conduction delay or failure) or repolarization disorder (ie, transmural repolarization gradient through the right ventricular wall). ${ }^{52}$ More significantly, the theory of loss of function of $\mathrm{Na}_{\mathrm{v}} 1.5$ or other ion channels as the basis has been questioned. This is because (1) there is often lack of a hereditary (familial) pattern in most index BrS patients, (2) sodium-channel blockers do not usually provoke the Brugada ECG pattern in normal subjects, and (3) the ECG pattern can also be seen or provoked in patients with structural heart diseases. Hence, it has been suggested that $\mathrm{BrS}$ is a multifactorial disorder with various causes of right ventricular conduction disturbances, of which "currentto-load mismatch" is the common denominator; different etiologies may require different approaches to management of cardiac arrhythmias in patients with $\mathrm{BrS}^{52}$

Of therapeutic relevance are two recent reports. In nine BrS patients treated with implantation of cardioverter/ defibrillators because of recurrent VF, Nademanee et $\mathrm{al}^{62}$ noted that all these nine patients had typical Brugada ECG pattern and electrically inducible VT/VF. Electrophysiological mapping revealed the presence of low-voltage, fractionated late potentials spanning beyond the electrocardiographic QRS complex, clustering exclusively in the RVOT anterior aspect during sinus rhythm. Because the magnitude of these electrogram abnormalities over the epicardium was much greater than those recorded in the endocardium, the researchers applied radiofrequency catheter ablation at these sites; as a result, the Brugada ECG pattern became normalized in eight patients (89\%) and VT/VF rendered electrically noninducible in seven patients $(78 \%)$. All patients were off medication except for one (amiodarone therapy continued), and there was no recurrence of $\mathrm{VT} / \mathrm{VF}$ observed in any patients 
during a follow-up period of $20 \pm 6$ months. The study has demonstrated that the BrS ECG pattern can be accounted for by delayed depolarization over the anterior aspect of RVOT. Moreover, in ten BrS patients, Sunsaneewitayakul et al ${ }^{63}$ noted a late activation zone recorded as electrical activity occurring from the $\mathrm{J}$ point to $+60(\mathrm{~J}+60)$ millisecond interval of $\mathrm{V}_{1}$ or $\mathrm{V}_{2}$ ECG lead in the RVOT endocardium during an isopotential mapping. Radiofrequency endocardial catheter ablation of the late-activation zone modified the Brugada ECG pattern in three $(75 \%)$ of four patients with VF storm. During a follow-up period of 12-30 months, there was no recurrence of VF in any of these four patients (100\%). It seems that the endocardium of RVOT can be considered as an alternative site for radiofrequency catheter ablation in the treatment of recurrent VF in BrS.

\section{Technology of induced pluripotent stem cells as a promising diagnostic and research tool in inherited arrhythmogenic disorders}

Electrophysiological characteristics of the mouse and human hearts are distinctly different in the distribution of ion channels, AP morphology, and heart rate. ${ }^{64} \mathrm{~A}$ mouse model may not always demonstrate the same phenotype as humans. Therefore, the use of induced pluripotent stem cell (iPSC) technology to study inherited arrhythmogenic disorders has become a new paradigm, as it can provide direct evidence linking genetic mutations to cardiac arrhythmias in humans. ${ }^{65,66}$ The iPSC technology is to reprogram somatic cells into pluripotent stem cells via transduction of a key set of transcriptional factors (eg, c-Myc, Oct3/4, Sox2, and Klf4 or Oct3/4, Sox2, Nanog, and Lin28). These iPSCs can then differentiate into the cell types of the three germ layers, and when generated from human somatic cells, the human iPSCs resemble those of human embryonic stem cells (ESCs) in morphology, gene expression, and epigenetic status of pluripotent cell-specific genes. ${ }^{67}$ Human iPSCs can differentiate to functional cardiac myocytes (CMs), ${ }^{68}$ and similar to human ESCs these human iPSCs possess a capacity of differentiating into nodal-, atrial-, and ventricular-like cells, each with specific AP characteristics; both iPSC- and ESC-derived CMs exhibit typical responsiveness to BAS. Consequently, the possibility of creating patient- and diseasespecific human iPSC-derived CMs aimed at individualized diagnostic and pharmacological testing has become a reality. To date, iPSC-derived CMs have been assessed in a limited number of patients with ion channelopathies. ${ }^{65,66}$

\section{LQTI}

In iPSC-derived $\mathrm{CMs}$ produced from two patients with KCNQ1 ${ }^{\mathrm{R} 190 \mathrm{Q}}$ mutation, ${ }^{69}$ functional study revealed a dominant negative trafficking defect associated with a $70 \%-80 \%$ reduction in $I_{\mathrm{Ks}}$ alongside altered activation and deactivation properties of $\mathrm{K}_{\mathrm{v}} \mathrm{LQT1}$. Compared to control, these iPSC-derived CMs with $\mathrm{KCNQ} 1^{\mathrm{R} 190 \mathrm{Q}}$ showed increased propensity to EADs in response to isoproterenol, which could be attenuated by propranolol. ${ }^{69}$ These findings are in accord with clinical observations that cardiac events are usually triggered by enhanced sympathetic tone and that $\beta$-blockers are beneficial in LQT1. ${ }^{70}$

\section{LQT2}

In iPSC-derived CMs produced from a patient with $\mathrm{A} 614 \mathrm{~V}$ missense in $\mathrm{KCNH} 2,{ }^{71}$ there was prolongation of AP duration, which could be ascribed to significant reduction of $I_{\mathrm{Kr}}$. These iPSC-derived $\mathrm{CMs}$ with $\mathrm{KCNH} 2^{\mathrm{A} 614}$ also exhibited marked arrhythmogenicity characterized by EADs and EADmediated TA. $\mathrm{K}^{+}$-channel blockers could aggravate, whereas $\mathrm{Ca}^{2+}$-channel blockers, $I_{\mathrm{K}(\mathrm{ATP})}$-channel openers, and late $\mathrm{Na}^{+}$channel blockers could ameliorate the disease phenotype. ${ }^{71}$ In another patient with $\mathrm{KCNH}^{\mathrm{G} 1681 \mathrm{~A}}$, iPSC-derived $\mathrm{CMs}^{72}$ also showed prolonged AP duration. Exposure to E4031 (an $I_{\mathrm{Kr}}$ blocker) provoked EADs. Moreover, isoprenaline facilitated EADs; this latter effect could be reversed by $\beta$-blockers. ${ }^{72}$

In an asymptomatic patient with $\mathrm{KCNH} 2^{\mathrm{R} 176 \mathrm{~W}}$ whose sister and father had died suddenly at an early age, iPSCderived $\mathrm{CMs}$ with such a mutation showed prolonged AP duration and significantly reduced $I_{\mathrm{Kr}}$ density. ${ }^{73}$ These iPSCderived $\mathrm{CMs}$ with $\mathrm{KCNH} 2^{\mathrm{R} 176 \mathrm{~W}}$ were sensitive to potentially arrhythmogenic drugs such as sotalol, and exhibited a pronounced inverse correlation between the beating rate and repolarization time. Hence, iPSC-derived CMs may be used to provide a direct way for identifying asymptomatic patients at risk of proarrhythmia.

\section{LQT3}

iPSC-derived CMs were produced from a mouse model with a human LQT3 mutation of $\mathrm{Na}_{\mathrm{v}} 1.5 .^{74}$ These iPSC-derived CMs showed biophysical effects of the mutation on $\mathrm{Na}_{\mathrm{v}} 1.5$, ie, faster recovery from inactivation and larger late currents than those of the wild-type control, prolonged AP duration, and development of EADs at low pacing rates, consistent with classic features of LQT3.

In a mouse model, iPSC-derived CMs carrying SCN5 $\mathrm{A}^{1798 \mathrm{ins} /+}$ mutation $^{75}$ showed a decrease in $I_{\mathrm{Na}}$ density with a large persistent $I_{\mathrm{Na}}$ and reduced AP upstroke velocity coupled with prolonged AP duration. These 
electrophysiological characteristics were subsequently observed in iPSC-derived CMs generated from a patient with equivalent $\mathrm{SCN} 5 \mathrm{~A}^{1795 \mathrm{ins} / /}$ mutation. Of note, this latter mutation clinically gave rise to a phenotype of LQT3 and $\mathrm{BrS}$ with conduction defects due to both gain- and loss-offunction effects on $\mathrm{Na}_{\mathrm{v}} 1.5$, respectively. ${ }^{76}$

\section{LQT8}

Human iPSC-derived CMs generated from two patients with TS (LQT8) showed irregular contractions, excessive $\mathrm{Ca}^{2+}$ influx, and markedly prolonged AP duration (three times longer than that of the wild-type control) ${ }^{77}$ irregular electrical activity and abnormal intracellular $\mathrm{Ca}^{2+}$ transients associated with delayed inactivation of $\mathrm{Ca}_{\mathrm{v}}$ 1.2. Roscovitine, a compound that increases VDI of $\mathrm{Ca}_{\mathrm{v}} 1.2$, was able to revert delayed inactivation of $\mathrm{Ca}_{\mathrm{v}} 1.2$ and restored irregular intracellular $\mathrm{Ca}^{2+}$ transients.

\section{CPVT}

iPSC-derived CMs created from a patient with RyR2 ${ }^{\mathrm{F} 24831}$ heterozygous mutation showed high amplitude and long duration of spontaneous $\mathrm{Ca}^{2+}$ release at basal state. ${ }^{78} \mathrm{In}$ response to catecholaminergic stimulation, these iPSCderived CMs were prone to DADs, which paradoxically could be abolished by increasing the cytosolic cAMP level with forskolin. iPSC-derived CMs were also produced from a CPVT patient with RyR2 ${ }^{\mathrm{M} 4109 \mathrm{R}}$ heterozygous mutation. In the presence of isoproterenol or forskolin, these CPVT iPSCderived $\mathrm{CMs}$ readily developed DADs and DAD-mediated TA related to SOICR, which could be improved with $\beta$-blockers and could be eliminated by both flecainide and thapsigargin (an $I_{\text {up }}$ inhibitor); ${ }^{71}$ the threshold of SOICR was significantly reduced in these CPVT human iPSC-derived CMs.

Lastly, in iPSC-derived CMs produced from a CPVT patient carrying $\mathrm{RyR} 2^{\mathrm{S} 406 \mathrm{~L}}$ mutation, ${ }^{79}$ catecholamines led to an increase in diastolic intracellular $\mathrm{Ca}^{2+}$ transients and a reduced SR $\mathrm{Ca}^{2+}$ content coupled with an increased susceptibility to DADs due to increased frequency and duration of $\mathrm{Ca}^{2+}$ sparks. Dantrolene, a drug effective for treating malignant hyperthermia (presumably via inhibiting the ryanodine receptor) was able to rescue arrhythmogenic properties of CPVT iPSC-derived CMs.

\section{Genotype-phenotype correlation and risk stratification in congenital LQTS}

Clinically relevant genotype-phenotype relationships have been investigated in the ECG ST-T waves, responses to epinephrine, types of arrhythmogenic trigger, responsiveness to antiarrhythmic agents, and risk stratification. ${ }^{80-82}$ Characteristically, an arrhythmic event is frequently exertiontriggered in LQT1 and auditory-triggered in LQT2, and by contrast it usually occurs at rest in LQT3. $\beta$-blocker therapy is most effective in LQT1 followed by LQT2 and least effective in LQT3; in fact, it should be considered contraindicated in LQT3. ${ }^{70}$ Because $I_{\mathrm{Ks}}, I_{\mathrm{Kr}}, I_{\mathrm{NaK}}, I_{\mathrm{K} 1}$, and $I_{\mathrm{Ca}, \mathrm{L}}$ are catecholaminesensitive, the trigger of arrhythmic events is often related to enhanced sympathetic tone in certain congenital LQTS, such as LQT1 $\left(K C N Q 1-I_{\mathrm{Ks}}\right)$, LQT2 (KCNH2-I $\left.I_{\mathrm{Kr}}\right)$, LQT4 (ANK2$\left.I_{\mathrm{NaK}}, I_{\mathrm{NaCa}}, \mathrm{IP}_{3}\right), \mathrm{LQT} 5\left(K C N E-I_{\mathrm{Ks}}\right), \mathrm{LQT} 7\left(K C N J 2-I_{\mathrm{K} 1}\right), \mathrm{LQT} 8$ $\left(C A C N A 1 C-I_{\mathrm{Ca}, \mathrm{L}}\right)$, and LQT11 $\left(A K A P 9-I_{\mathrm{Ks}}\right)$. An arrhythmic event triggered by swimming is relatively specific for LQT $1,{ }^{70}$ but it also has been reported in cases of CPVT and LQT7. ${ }^{17}$

LQT1, LQT2 and LQT3 constitute the majority (approximately 65\%-75\%) of congenital LQTS. ${ }^{83}$ Among these three subtypes, it has been suggested that the prognostic value might be assigned according to the location of a particular mutation. In LQT2, Moss et $\mathrm{al}^{84}$ noticed that patients with mutations in the pore region of the $\mathrm{KCNH} 2$-encoded $\mathrm{K}^{+}$channel $\left(\mathrm{K}_{\mathrm{v}} 11.1\right)$ did worse than those who harbored mutations in the C-terminus. Similarly, Migdalovich et $\mathrm{al}^{85}$ found that pore-loop mutations displayed a significant higher risk in men ( $>$ twofold) than in women, but overall women were more vulnerable than men to life-threatening cardiac events (26\% vs $14 \%$ ). Furthermore, Kim et al ${ }^{86}$ noted that the type of trigger, in addition to sex, location of mutations, and QTc interval ( $\geq 500 \mathrm{~m}$ ), was an important risk factor for arrhythmic events in LQT2; risk factors for arousal-triggered cardiac events included sex (female: male $>13$ years: hazard ratio $[\mathrm{HR}]=9.10, P<0.001)$ and the presence of pore-loop mutations $(\mathrm{HR}=2.19, P=0.009)$, and $\beta$-blocker therapy was beneficial in patients with exercise-triggered events (HR $=0.29, P<0.01)$, but not in those with arousal and nonexercise/nonarousal events.

Similarly, in LQT1 patients, Shimizu et al ${ }^{87}$ reported that patients with mutations involving the transmembranespanning domains and/or pore regions of $\mathrm{K}_{\mathrm{v}} \mathrm{LQT} 1$ had a poorer outcome compared to those harboring mutations in the $\mathrm{C}$-terminus. Crotti et $\mathrm{al}^{88}$ noted that LQT1 mutation KCNQ1 ${ }^{\mathrm{A} 341 \mathrm{~V}}$ was associated with a high clinical severity (SCD rate $14 \%$ ) despite $\beta$-blocker therapy. These KCNQ1 ${ }^{\mathrm{A} 341 \mathrm{~V}}$ patients were more likely to have a longer QTc interval (485 \pm 43 vs $465 \pm 38$ milliseconds), cardiac events ( $75 \%$ vs $24 \%$ ), and were younger at first event (6 vs 11 years) compared to non-A341V patients. Moreover, this 
KCNQ1 A341V "hot spot" was predictive of high clinical severity independent of ethnic origin.

Nevertheless, it is well appreciated that variable expressivity and "genotype-phenotype violation" are not infrequently encountered in "inheritable arrhythmogenic disorders," presumably due to incomplete penetrance, epigenetic factors, and gene-to-gene interaction (eg, compound mutations, modifier genes, polymorphisms, etc)..$^{80,89-91}$ Consequently, the concept of a malignant domain should not be generally applied. ${ }^{90}$ In genotype-positive and phenotype-negative patients, genotype (including the site of mutation), age, sex, family history, and the QTc interval all need to be taken into consideration while contemplating preventive strategy with lifestyle adjustment, pharmacotherapy, and/or prophylactic implantation of an implantable cardioverter/defibrillator. ${ }^{80,90,92}$

\section{Conclusion}

Our current understanding of the pathophysiology of inherited arrhythmogenic disorders has come mostly from intensive and extensive investigations of ion channelopathies, especially congenital LQTS and others like CPVT and BrS over the past 15 years. The accumulated knowledge of the functionality of each ion channel in relation to gene mutations has facilitated research and development of more effective targeted pharmacotherapy and nonpharmacological treatment modalities, such as gene therapy and catheter ablation.

Technology with the ability to generate human iPSCs ${ }^{67,68}$ has become a new paradigm for pathophysiological study of patient- and disease-specific cells and for screening of new drugs, and clinical application of gene therapy. However, because this technology is relatively new, the validity and reproducibility of the findings need to be carefully verified. Human iPSC-derived CMs are usually immature, more akin to fetal $\mathrm{CMs}$, as yet to recapitulate all the characteristics of adult CMs. Moreover, better purification of human iPSCderived CMs is needed, as they often represent a mixture of cell types - atrial, nodal, and ventricular - that display various electrophysiological properties; as a result, $\mathrm{CMs}$ so derived might not fully exhibit disease-specific phenotypic features. Further refinement of the technology (eg, the method used for cell isolation and cultivation, selection of CM-specific promoters, etc) is currently under way. ${ }^{65,66}$ It is anticipated that continued efforts and collaboration between clinical and basic science researchers are required to overcome difficulties concerning the use of iPSC technology in the diagnosis and management of arrhythmic disorders in clinical practice.

\section{Acknowledgments}

This work was in part supported by grants from the Ministry of Education (Development Plan for World Class Universities and Research Centers of Excellence - National Central University).

\section{Disclosure}

The authors report no conflicts of interest in this work.

\section{References}

1. Sanger F, Coulson AR. A rapid method for determining sequences in DNA by primed synthesis with DNA polymerase. J Mol Biol. 1975;94(3): 441-448.

2. Curran ME, Splawski I, Timothy KW, Vincent GM, Green ED, Keating MT. A molecular basis for cardiac arrhythmia: HERG mutations cause long QT syndrome. Cell. 1995;80(5):795-803.

3. Wang Q, Curran ME, Splawski I, et al. Positional cloning of a novel potassium channel gene: KVLQT1 mutations cause cardiac arrhythmias. Nat Genet. 1996;12(1):17-23.

4. Wang Q, Shen J, Splawski I, et al. SCN5A mutations associated with an inherited cardiac arrhythmia, long QT syndrome. Cell. 1995;80(5): 805-811.

5. Watanabe H, Koopmann TT, Le Scouarnec S, et al. Sodium channel beta1 subunit mutations associated with Brugada syndrome and cardiac conduction disease in humans. J Clin Invest. 2008;118(6): 2260-2268.

6. Sabir IN, Killeen MJ, Grace AA, Huang CL. Ventricular arrhythmogenesis: insights from murine models. Prog Biophys Mol Biol. 2008;98(2-3): 208-218.

7. Schwartz PJ, Priori SG, Spazzolini C, et al. Genotype-phenotype correlation in the long-QT syndrome: gene-specific triggers for life-threatening arrhythmias. Circulation. 2001;103(1):89-95.

8. Ackerman MJ, Mohler PJ. Defining a new paradigm for human arrhythmia syndromes: phenotypic manifestations of gene mutations in ion channel- and transporter-associated proteins. Circ Res. 2010;107(4): 457-465.

9. Mohler PJ, Schott JJ, Gramolini AO, et al. Ankyrin-B mutation causes type 4 long-QT cardiac arrhythmia and sudden cardiac death. Nature. 2003;421(6923):634-639.

10. Vatta M, Ackerman MJ, Ye B, et al. Mutant caveolin-3 induces persistent late sodium current and is associated with long-QT syndrome. Circulation. 2006;114(20):2104-2112.

11. Woodman SE, Park DS, Cohen AW, et al. Caveolin-3 knockout mice develop a progressive cardiomyopathy and show hyperactivation of the p42/44 MAPK cascade. $J$ Biol Chem. 2002;277(41):38988-38997.

12. Cronk LB, Ye B, Kaku T, et al. Novel mechanism for sudden infant death syndrome: persistent late sodium current secondary to mutations in caveolin-3. Heart Rhythm. 2007;4(2):161-166.

13. Chen L, Marquardt ML, Tester DJ, Sampson KJ, Ackerman MJ, Kass RS. Mutation of an A-kinase-anchoring protein causes long-QT syndrome. Proc Natl Acad Sci U S A. 2007;104(52):20990-20995.

14. Aarnoudse AJ, Newton-Cheh C, de Bakker PI, et al. Common NOS1 AP variants are associated with a prolonged QTc interval in the Rotterdam Study. Circulation. 2007;116(1):10-16.

15. Arking DE, Pfeufer A, Post W, et al. A common genetic variant in the NOS1 regulator NOS1AP modulates cardiac repolarization. Nat Genet. 2006;38(6):644-651.

16. Plaster NM, Tawil R, Tristani-Firouzi M, et al. Mutations in Kir2.1 cause the developmental and episodic electrical phenotypes of Andersen's syndrome. Cell. 2001;105(4):511-519.

17. Tristani-Firouzi M, Etheridge SP. Kir 2.1 channelopathies: the Andersen-Tawil syndrome. Pflugers Arch. 2010;460(2):289-294. 
18. Zhang L, Benson DW, Tristani-Firouzi M, et al. Electrocardiographic features in Andersen-Tawil syndrome patients with KCNJ2 mutations: characteristic T-U-wave patterns predict the KCNJ2 genotype. Circulation. 2005;111(21):2720-2726.

19. Lopatin AN, Nichols CG. Inward rectifiers in the heart: an update on I(K1). J Mol Cell Cardiol. 2001;33(4):625-638.

20. Barajas-Martinez H, Hu D, Ontiveros G, et al. Biophysical and molecular characterization of a novel de novo KCNJ2 mutation associated with Andersen-Tawil syndrome and catecholaminergic polymorphic ventricular tachycardia mimicry. Circ Cardiovasc Genet. 2011;4(1): 51-57.

21. Tsuboi M, Antzelevitch C. Cellular basis for electrocardiographic and arrhythmic manifestations of Andersen-Tawil syndrome (LQT7). Heart Rhythm. 2006;3(3):328-335.

22. Tester DJ, Arya P, Will M, et al. Genotypic heterogeneity and phenotypic mimicry among unrelated patients referred for catecholaminergic polymorphic ventricular tachycardia genetic testing. Heart Rhythm. 2006;3(7):800-805.

23. Vega AL, Tester DJ, Ackerman MJ, Makielski JC. Protein kinase A-dependent biophysical phenotype for V227F-KCNJ2 mutation in catecholaminergic polymorphic ventricular tachycardia. Circ Arrhythm Electrophysiol. 2009;2(5):540-547.

24. Liu N, Priori SG. Disruption of calcium homeostasis and arrhythmogenesis induced by mutations in the cardiac ryanodine receptor and calsequestrin. Cardiovasc Res. 2008;77(2):293-301.

25. Splawski I, Timothy KW, Sharpe LM, et al. Ca(V)1.2 calcium channel dysfunction causes a multisystem disorder including arrhythmia and autism. Cell. 2004;119(1):19-31.

26. Splawski I, Timothy KW, Decher N, et al. Severe arrhythmia disorder caused by cardiac L-type calcium channel mutations. Proc Natl Acad Sci U S A. 2005;102(23):8089-8096; discussion 8086-8088.

27. Navedo MF, Cheng EP, Yuan C, et al. Increased coupled gating of L-type $\mathrm{Ca} 2+$ channels during hypertension and Timothy syndrome Circ Res. 2010;106(4):748-756.

28. Erxleben C, Liao Y, Gentile S, et al. Cyclosporin and Timothy syndrome increase mode 2 gating of CaV1.2 calcium channels through aberrant phosphorylation of S6 helices. Proc Natl Acad Sci USA. 2006;103(10): 3932-3937.

29. Yarotskyy V, Gao G, Peterson BZ, Elmslie KS. The Timothy syndrome mutation of cardiac CaV1.2 (L-type) channels: multiple altered gating mechanisms and pharmacological restoration of inactivation. J Physiol. 2009;587(Pt 3):551-565.

30. Sicouri S, Timothy KW, Zygmunt AC, et al. Cellular basis for the electrocardiographic and arrhythmic manifestations of Timothy syndrome: effects of ranolazine. Heart Rhythm. 2007;4(5):638-647.

31. Sung RJ, Wu YH, Lai NH, et al. Beta-adrenergic modulation of arrhythmogenesis and identification of targeted sites of antiarrhythmic therapy in Timothy (LQT8) syndrome: a theoretical study. Am J Physiol Heart Circ Physiol. 2010;298(1):H33-H44.

32. Cheng EP, Yuan C, Navedo MF, et al. Restoration of normal L-type $\mathrm{Ca} 2+$ channel function during Timothy syndrome by ablation of an anchoring protein. Circ Res. 2011;109(3):255-261.

33. Cerrone M, Colombi B, Santoro M, et al. Bidirectional ventricular tachycardia and fibrillation elicited in a knock-in mouse model carrier of a mutation in the cardiac ryanodine receptor. Circ Res. 2005;96(10): e77-e82.

34. Liu N, Colombi B, Memmi M, et al. Arrhythmogenesis in catecholaminergic polymorphic ventricular tachycardia: insights from a RyR2 R4496C knock-in mouse model. Circ Res. 2006;99(3): 292-298.

35. Fernandez-Velasco M, Rueda A, Rizzi N, et al. Increased Ca2+ sensitivity of the ryanodine receptor mutant RyR2R4496C underlies catecholaminergic polymorphic ventricular tachycardia. Circ Res. 2009; 104(2):201-209, 12p following 209.

36. Sedej S, Heinzel FR, Walther S, et al. Na+-dependent SR Ca2+ overload induces arrhythmogenic events in mouse cardiomyocytes with a human CPVT mutation. Cardiovasc Res. 2010;87(1):50-59.
37. Kang G, Giovannone SF, Liu N, et al. Purkinje cells from RyR2 mutant mice are highly arrhythmogenic but responsive to targeted therapy. Circ Res. 2010;107(4):512-519.

38. Sinha AM, Schmidt M, Marschang H, et al. Role of left ventricular scar and Purkinje-like potentials during mapping and ablation of ventricular fibrillation in dilated cardiomyopathy. Pacing Clin Electrophysiol. 2009;32(3):286-290.

39. Terentyev D, Kubalova Z, Valle G, et al. Modulation of SR Ca release by luminal $\mathrm{Ca}$ and calsequestrin in cardiac myocytes: effects of CASQ2 mutations linked to sudden cardiac death. Biophys J. 2008;95(4): 2037-2048.

40. Gyorke I, Hester N, Jones LR, Gyorke S. The role of calsequestrin, triadin, and junctin in conferring cardiac ryanodine receptor responsiveness to luminal calcium. Biophys $J$. 2004;86(4):2121-2128.

41. Knollmann BC, Chopra N, Hlaing T, et al. Casq2 deletion causes sarcoplasmic reticulum volume increase, premature $\mathrm{Ca} 2+$ release, and catecholaminergic polymorphic ventricular tachycardia. J Clin Invest. 2006;116(9):2510-2520.

42. Kirchhefer U, Wehrmeister D, Postma AV, et al. The human CASQ2 mutation $\mathrm{K} 206 \mathrm{~N}$ is associated with hyperglycosylation and altered cellular calcium handling. J Mol Cell Cardiol. 2010;49(1):95-105.

43. Priori SG, Chen SR. Inherited dysfunction of sarcoplasmic reticulum $\mathrm{Ca} 2+$ handling and arrhythmogenesis. Circ Res. 2011;108(7):871-883.

44. Sung RJ, Lo CP, Hsiao PY, Tien HC. Targeting intracellular calcium cycling in catecholaminergic polymorphic ventricular tachycardia: a theoretical investigation. Am J Physiol Heart Circ Physiol. 2011; 301(4):H1625-H1638.

45. Hilliard FA, Steele DS, Laver D, et al. Flecainide inhibits arrhythmogenic $\mathrm{Ca} 2+$ waves by open state block of ryanodine receptor $\mathrm{Ca} 2+$ release channels and reduction of $\mathrm{Ca} 2+$ spark mass. J Mol Cell Cardiol. 2010;48(2):293-301.

46. van der Werf C, Kannankeril PJ, Sacher F, et al. Flecainide therapy reduces exercise-induced ventricular arrhythmias in patients with catecholaminergic polymorphic ventricular tachycardia. J Am Coll Cardiol. 2011;57(22):2244-2254.

47. Watanabe H, Chopra N, Laver D, et al. Flecainide prevents catecholaminergic polymorphic ventricular tachycardia in mice and humans. Nat Med. 2009;15(4):380-383.

48. Katritsis D, Rowland E, O'Nunain S, Shakespeare CF, Poloniecki J, Camm AJ. Effect of flecainide on atrial and ventricular refractoriness and conduction in patients with normal left ventricle. Implications for possible antiarrhythmic and proarrhythmic mechanisms. Eur Heart J. 1995;16(12):1930-1935.

49. Liu N, Denegri M, Ruan YF, et al. Sodium channel blockers prevent triggered activity but not abnormal $\mathrm{Ca} 2+$ release in a knock-in mouse model with ryanodine receptor mutation R4496C. Circulation. 2010;122(21):A13707.

50. Caballero R, Dolz-Gaiton P, Gomez R, et al. Flecainide increases Kir2.1 currents by interacting with cysteine 311, decreasing the polyamine-induced rectification. Proc Natl Acad Sci U S A. 2010; 107(35):15631-15636.

51. Liu N, Ruan Y, Denegri M, et al. Calmodulin kinase II inhibition prevents arrhythmias in RyR2(R4496C+/-) mice with catecholaminergic polymorphic ventricular tachycardia. J Mol Cell Cardiol. 2011;50(1): 214-222.

52. Hoogendijk MG. Diagnostic dilemmas: overlapping features of Brugada syndrome and arrhythmogenic right ventricular cardiomyopathy. Front Physiol. 2012;3:144.

53. Nademanee K, Veerakul G, Nimmannit S, et al. Arrhythmogenic marker for the sudden unexplained death syndrome in Thai men. Circulation. 1997;96(8):2595-2600.

54. Chen Q, Kirsch GE, Zhang D, et al. Genetic basis and molecular mechanism for idiopathic ventricular fibrillation. Nature. 1998; 392(6673):293-296.

55. Hu D, Barajas-Martinez H, Burashnikov E, et al. A mutation in the beta 3 subunit of the cardiac sodium channel associated with Brugada ECG phenotype. Circ-Cardiovasc Gene. 2009;2(3):270-278. 
56. London B, Michalec M, Mehdi $\mathrm{H}$, et al. Mutation in glycerol3-phosphate dehydrogenase 1 like gene (GPD1-L) decreases cardiac $\mathrm{Na}+$ current and causes inherited arrhythmias. Circulation. 2007;116(20):2260-2268.

57. Kattygnarath D, Maugenre S, Neyroud N, et al. MOG1: a new susceptibility gene for Brugada syndrome. Circ Cardiovasc Genet. 2011;4(3):261-268.

58. Antzelevitch C, Pollevick GD, Cordeiro JM, et al. Loss-of-function mutations in the cardiac calcium channel underlie a new clinical entity characterized by ST-segment elevation, short QT intervals, and sudden cardiac death. Circulation. 2007;115(4):442-449.

59. Burashnikov E, Pfeiffer R, Barajas-Martinez H, et al. Mutations in the cardiac L-type calcium channel associated with inherited J-wave syndromes and sudden cardiac death. Heart Rhythm. 2010;7(12): 1872-1882.

60. Delpón E, Cordeiro JM, Núñez L, et al. Functional effects of KCNE3 mutation and its role in the development of Brugada syndrome. Circ Arrhythm Electrophysiol. 2008;1(3):209-218.

61. Barajas-Martínez H, Hu D, Ferrer T, et al. Molecular genetic and functional association of Brugada and early repolarization syndromes with S422L missense mutation in KCNJ8. Heart Rhythm. 2012;9(4): 548-555.

62. Nademanee K, Veerakul G, Chandanamattha P, et al. Prevention of ventricular fibrillation episodes in Brugada syndrome by catheter ablation over the anterior right ventricular outflow tract epicardium. Circulation. 2011;123(12):1270-1279.

63. Sunsaneewitayakul B, Yao Y, Thamaree S, Zhang S. Endocardial mapping and catheter ablation for ventricular fibrillation prevention in Brugada syndrome. J Cardiovasc Electrophysiol. 2012;23 Suppl 1: s10-s16.

64. Watanabe H, Yang T, Stroud DM, et al. Striking in vivo phenotype of a disease-associated human SCN5A mutation producing minimal changes in vitro. Circulation. 2011;124(9):1001-1011.

65. Hoekstra M, Mummery CL, Wilde AA, Bezzina CR, Verkerk AO. Induced pluripotent stem cell derived cardiomyocytes as models for cardiac arrhythmias. Front Physiol. 2012;3:346.

66. Yoshida Y, Yamanaka S. Recent stem cell advances: induced pluripotent stem cells for disease modeling and stem cell-based regeneration. Circulation. 2010;122(1):80-87.

67. Takahashi K, Tanabe K, Ohnuki M, et al. Induction of pluripotent stem cells from adult human fibroblasts by defined factors. Cell. 2007;131(5): 861-872.

68. Zhang J, Wilson GF, Soerens AG, et al. Functional cardiomyocytes derived from human induced pluripotent stem cells. Circ Res. 2009; 104(4):e30-e41.

69. Moretti A, Bellin M, Welling A, et al. Patient-specific induced pluripotent stem-cell models for long-QT syndrome. N Engl J Med. 2010; 363(15):1397-1409

70. Moss AJ, Kass RS. Long QT syndrome: from channels to cardiac arrhythmias. J Clin Invest. 2005;115(8):2018-2024.

71. Itzhaki I, Maizels L, Huber I, et al. Modelling the long QT syndrome with induced pluripotent stem cells. Nature. 2011;471(7337):225-229.

72. Matsa E, Rajamohan D, Dick E, et al. Drug evaluation in cardiomyocytes derived from human induced pluripotent stem cells carrying a long QT syndrome type 2 mutation. Eur Heart J. 2011;32(8):952-962.

73. Lahti AL, Kujala VJ, Chapman H, et al. Model for long QT syndrome type 2 using human iPS cells demonstrates arrhythmogenic characteristics in cell culture. Dis Model Mech. 2012;5(2):220-230.

74. Malan D, Friedrichs S, Fleischmann BK, Sasse P. Cardiomyocytes obtained from induced pluripotent stem cells with long-QT syndrome 3 recapitulate typical disease-specific features in vitro. Circ Res. 2011; 109(8):841-847.

75. Davis RP, Casini S, van den Berg CW, et al. Cardiomyocytes derived from pluripotent stem cells recapitulate electrophysiological characteristics of an overlap syndrome of cardiac sodium channel disease. Circulation. 2012;125(25):3079-3091.
76. Remme CA, Verkerk AO, Nuyens D, et al. Overlap syndrome of cardiac sodium channel disease in mice carrying the equivalent mutation of human SCN5A-1795insD. Circulation. 2006;114(24):2584-2594.

77. Yazawa M, Hsueh B, Jia X, et al. Using induced pluripotent stem cells to investigate cardiac phenotypes in Timothy syndrome. Nature. 2011;471(7337):230-234

78. Fatima A, Xu G, Shao K, et al. In vitro modeling of ryanodine receptor 2 dysfunction using human induced pluripotent stem cells. Cell Physiol Biochem. 2011;28(4):579-592.

79. Jung CB, Moretti A, Mederos y Schnitzler M, et al. Dantrolene rescues arrhythmogenic RYR2 defect in a patient-specific stem cell model of catecholaminergic polymorphic ventricular tachycardia. EMBO Mol Med. 2012;4(3):180-191.

80. Ackerman MJ. Genetic testing for risk stratification in hypertrophic cardiomyopathy and long QT syndrome: fact or fiction? Curr Opin Cardiol. 2005;20(3):175-181.

81. Goldenberg I, Bradley J, Moss A, et al. Beta-blocker efficacy in high-risk patients with the congenital long-QT syndrome types 1 and 2: implications for patient management. $J$ Cardiovasc Electrophysiol. 2010;21(8):893-901.

82. Liu JF, Jons C, Moss AJ, et al. Risk factors for recurrent syncope and subsequent fatal or near-fatal events in children and adolescents with long QT syndrome. J Am Coll Cardiol. 2011;57(8):941-950.

83. Tester DJ, Will ML, Haglund CM, Ackerman MJ. Compendium of cardiac channel mutations in 541 consecutive unrelated patients referred for long QT syndrome genetic testing. Heart Rhythm. 2005;2(5):507-517.

84. Moss AJ, Zareba W, Kaufman ES, et al. Increased risk of arrhythmic events in long-QT syndrome with mutations in the pore region of the human ether-a-go-go-related gene potassium channel. Circulation. 2002;105(7):794-799.

85. Migdalovich D, Moss AJ, Lopes CM, et al. Mutation and gender-specific risk in type 2 long QT syndrome: implications for risk stratification for life-threatening cardiac events in patients with long QT syndrome. Heart Rhythm. 2011;8(10):1537-1543.

86. Kim JA, Lopes CM, Moss AJ, et al. Trigger-specific risk factors and response to therapy in long QT syndrome type 2. Heart Rhythm. 2010;7(12):1797-1805.

87. Shimizu W, Horie M, Ohno S, et al. Mutation site-specific differences in arrhythmic risk and sensitivity to sympathetic stimulation in the LQT1 form of congenital long QT syndrome: multicenter study in Japan. $J$ Am Coll Cardiol. 2004;44(1):117-125.

88. Crotti L, Spazzolini C, Schwartz PJ, et al. The common long-QT syndrome mutation KCNQ1/A341V causes unusually severe clinical manifestations in patients with different ethnic backgrounds: toward a mutation-specific risk stratification. Circulation. 2007;116(21): 2366-2375.

89. Crotti L, Monti MC, Insolia R, et al. NOS1AP is a genetic modifier of the long-QT syndrome. Circulation. 2009;120(17):1657-1663.

90. Giudicessi JR, Ackerman MJ. Determinants of incomplete penetrance and variable expressivity in heritable cardiac arrhythmia syndromes. Transl Res. Epub September 17, 2012.

91. Kobori A, Sarai N, Shimizu W, et al. Additional gene variants reduce effectiveness of beta-blockers in the LQT1 form of long QT syndrome. J Cardiovasc Electrophysiol. 2004;15(2):190-199.

92. Priori SG, Schwartz PJ, Napolitano C, et al. Risk stratification in the long-QT syndrome. $N$ Engl J Med. 2003;348(19):1866-1874.

93. Splawski I, Tristani-Firouzi M, Lehmann MH, Sanguinetti MC, Keating MT. Mutations in the hminK gene cause long QT syndrome and suppress IKs function. Nat Genet. 1997;17(3):338-340.

94. Abbott GW, Sesti F, Splawski I, et al. MiRP1 forms IKr potassium channels with HERG and is associated with cardiac arrhythmia. Cell. 1999;97(2):175-187.

95. Ai T, Fujiwara Y, Tsuji K, et al. Novel KCNJ2 mutation in familial periodic paralysis with ventricular dysrhythmia. Circulation. 2002; 105(22):2592-2594. 
96. Ye B, Tester DJ, Vatta M, Makielski JC, Ackerman MJ. AB1-1: Molecular and functional characterization of novel cav3-encoded caveolin-3 mutations in congenital long QT syndrome. Heart Rhythm. 2006;3(5):S1

97. Domingo AM, Kaku T, Tester DJ, et al. AB16-6: sodium channel $\beta 4$ subunit mutation causes congenital long QT syndrome. Heart Rhythm. 2006;3(5):S34.

98. Medeiros-Domingo A, Kaku T, Tester DJ, et al. SCN4B-encoded sodium channel beta4 subunit in congenital long-QT syndrome. Circulation. 2007;116(2):134-142.

99. Ueda K, Valdivia C, Medeiros-Domingo A, et al. Syntrophin mutation associated with long QT syndrome through activation of the nNOSSCN5A macromolecular complex. Proc Natl Acad Sci U S A. 2008;105(27):9355-9360.

100. Wu G, Ai T, Kim JJ, et al. Alpha-1-syntrophin mutation and the long-QT syndrome: a disease of sodium channel disruption. Circ Arrhythm Electrophysiol. 2008;1(3):193-201.

101. Yang Y, Liang B, Liu J, et al. Identification of a Kir3.4 mutation in congenital long QT syndrome. Am J Hum Genet. 2010;86(6):872-880.

102. Kapplinger J, Wilde A, Antzelevitch C. A worldwide compendium of putative Brugada syndrome associated mutations in the SCN5A encoded cardiac sodium channel. Heart Rhythm. 2009;6:S392.

103. Schulze-Bahr E, Eckardt L, Breithardt G, et al. Sodium channel gene (SCN5A) mutations in 44 index patients with Brugada syndrome: different incidences in familial and sporadic disease. Hum Mutat. 2003;21(6):651-652.

104. Medeiros-Domingo A, Tan BH, Crotti L, et al. Gain-of-function mutation S422L in the KCNJ8-encoded cardiac K(ATP) channel Kir6.1 as a pathogenic substrate for J-wave syndromes. Heart Rhythm. 2010;7(10):1466-1471.

105. Giudicessi JR, Ye D, Tester DJ, et al. Transient outward current (I(to)) gain-of-function mutations in the KCND3-encoded Kv4.3 potassium channel and Brugada syndrome. Heart Rhythm. 2011;8(7):1024-1032.
106. Laitinen PJ, Brown KM, Piippo K, et al. Mutations of the cardiac ryanodine receptor (RyR2) gene in familial polymorphic ventricular tachycardia. Circulation. 2001;103(4):485-490.

107. Priori SG, Napolitano C, Tiso N, et al. Mutations in the cardiac ryanodine receptor gene (hRyR2) underlie catecholaminergic polymorphic ventricular tachycardia. Circulation. 2001;103(2):196-200.

108. Lahat H, Pras E, Olender T, et al. A missense mutation in a highly conserved region of CASQ2 is associated with autosomal recessive catecholamine-induced polymorphic ventricular tachycardia in Bedouin families from Israel. Am J Hum Genet. 2001;69(6):1378-1384.

109. Postma AV, Denjoy I, Hoorntje TM, et al. Absence of calsequestrin 2 causes severe forms of catecholaminergic polymorphic ventricular tachycardia. Circ Res. 2002;91(8):e21-e26.

110. Postma AV, Bhuiyan ZA, Shkolnikova M, et al. Involvement of the Kir2 gene family in catecholaminergic polymorphic ventricular tachycardia; analysis for mutations and identification of numerous pseudogenes. Eur Heart J. 2004;25:66.

111. Mohler PJ, Splawski I, Napolitano C, et al. A cardiac arrhythmia syndrome caused by loss of ankyrin-B function. Proc Natl Acad Sci US A. 2004;101(24):9137-9142.

112. Brugada R, Hong K, Dumaine R, et al. Sudden death associated with short-QT syndrome linked to mutations in HERG. Circulation. 2004;109(1):30-35.

113. Bellocq C, van Ginneken AC, Bezzina CR, et al. Mutation in the KCNQ1 gene leading to the short QT-interval syndrome. Circulation. 2004;109(20):2394-2397.

114. Priori SG, Pandit SV, Rivolta I, et al. A novel form of short QT syndrome (SQT3) is caused by a mutation in the KCNJ2 gene. Circ Res. 2005;96(7):800-807.

115. Templin C, Ghadri JR, Rougier JS, et al. Identification of a novel loss-of-function calcium channel gene mutation in short QT syndrome (SQTS6). Eur Heart J. 2011;32(9):1077-1088.
The Application of Clinical Genetics

\section{Publish your work in this journal}

The Application of Clinical Genetics is an international, peer-reviewed open access journal that welcomes laboratory and clinical findings in the field of human genetics. Specific topics include: Population genetics; Functional genetics; Natural history of genetic disease; Management of genetic disease; Mechanisms of genetic disease; Counseling and ethical

\section{Dovepress}

issues; Animal models; Pharmacogenetics; Prenatal diagnosis; Dysmorphology. The manuscript management system is completely online and includes a very quick and fair peer-review system, which is all easy to use. Visit http://www.dovepress.com/testimonials.php to read real quotes from published authors. 